\title{
TRACING THE IDENTITY AND AsCERTAINING the NATURE OF BRAHMI-DERIVED DEVANAGARI SCRIPT
}

\section{Krishna Kumar PANDEY}

Indian Institute of Technology Roorkee, India

Department of Humanities and Social Sciences

krishnapandeybuxar@gmail.com

\section{Smita JHA}

Indian Institute of Technology Roorkee, India Department of Humanities and Social Sciences smitaiitr@gmail.com

\begin{abstract}
Current research exploits the orthographic design of Brahmi-derived scripts (also called Indic scripts), particularly the Devanagari script. Earlier works on orthographic nature of Brahmi-derived scripts fail to create a consensus among epigraphists, historians or linguists, and thus have been identified by various names, like semi-syllabic, subsyllabic, semi-alphabetic, alphasyllabary or abugida. On the contrary, this paper argues that Brahmi-derived scripts should not be categorized as scripts with overlapping features of alphabetic and syllabic properties as these scripts are neither alphabetic nor syllabic. Historical evolution and linguistic properties of Indic scripts, particularly Devanagari, ascertain the need for a new categorization of its own and, thus preferably merit a unique descriptor. This paper investigates orthographic characteristics of the Brahmi-derived Devanagari script, current trends in research pertaining to the Devanagari script along with other Indic scripts and the implications of these findings for literacy development in Indic writing systems.
\end{abstract}

Keywords: orthography; Brahmi; Devanagari, akshara; alphasyllabary; alphabet

\section{Povzetek}

Raziskava obravnava ortografsko obliko pisav, ki izhajajo iz pisave brahmi (imenovane tudi indijske pisave), še posebej pisavo devanagari. Predhodnje študije o ortografski naravi the pisav niso uspele povezati mnenj epigrafov, zgodovinarjev in jezikoslovcev, zato je njihov opis zelo raznolik; uporabljajo se poimenovanja kot npr. polzlogovna, 
podzlogovna, alfa-zlogovna oz. abugida. $\mathrm{V}$ nasprotju s tem članek zagovarja idejo, da pisav, ki izvirajo iz pisave brahmi ne bi smeli označiti s podvajajočimi se značilnostmi abecenih in zlogovnih pisav, saj niso ne abecedni in ne zlogovni. Zgodovinski razvoj in jezikoslovne lastnosti indijskih pisav, še posebej pisave devanagari, nakazujejo na potrebo po oblikovanju nove kategorije, ki bi jo lahko poimenovali 'aksarske pisave'. Za konec članek ponuja kratek pregled razvoja pismenosti na področju aksarskih pisav.

Ključne besede: pisava, pisava brahmi; pisava devanagari, aksara; alfa-zlogovnica; latinica

\section{Introduction}

It has long been argued that 'pictures' can be quoted as the first instance of a kind of writing system. Interestingly, Gelb (1963), in his monumental work, categorises pictures under the first stage of writing, called "No Writing." He claims that a picture, which is an object of art, results from an artistic-aesthetic urge that fails to support theories of writing systems. However, under the heading of "Forerunners of Writing", he coined a term 'semasiography' which shows the stage in which pictures (here, he differentiated between artistic pictures and simple pictures) can convey general meanings. Certainly, Brahmi, an ancient Indic script does not make its appearance either in the category of 'no writing' or in 'semasiography'. It comes under the phonography, a category representing fully developed writing systems. Nevertheless, a question mark has always been put on the nature or identity of Brahmi or Brahmiderived scripts. Gelb (1963, p. 187) writes that "the forms of the individual signs of the Brahmi writings show no clear relationship with any other system, and were most probably freely invented." With these words, he raises a fundamental question on the nature of the linguistic organisation of Brahmi. The aim of this paper is to investigate orthographic characteristics of the Brahmi-derived Devanagari script, current trends in research pertaining to Brahmi-derived scripts and the implications of these findings for literacy development in akshara based writing systems.

\section{Theoretical Background}

It is well established that phonological structure plays a major role in defining the writing system of a language. The stream of sound segments of a spoken language is not perceived discretely but can be artificially segmented into individual phonological units. Syllable, a cluster of sounds, is a hierarchically structured phonological unit, which comprises an onset, a nucleus, and a coda to constitute different sound sequences of a language. In a syllable, nucleus is an obligatory component, while onset and coda are optional components. Of these, syllables without a coda are open 
syllables and syllables with a coda are closed syllables (Castles \& Coltheart, 2004; Gordon \& Ladefoged, 2001; P. Pandey, 2007).

Further, within a phonological system consonants and vowels act differently. Thus, the root form of a word is composed of two or three consonants, while vowels impart different grammatical aspects to it. This phenomenon is easily perceptible in Semitic languages (McCarthy, 1981). The theory of Dependency Phonology proclaims that human speech comprises three basic vowels $-/ \mathrm{a} /, / \mathrm{i} /$, and $/ \mathrm{u} /$, and others are produced from their amalgamation (Anderson \& Ewen, 1987). In addition, Government Phonology states that consonants carry an inherent short vowel, which is suppressed by individual languages in which it does not surface; otherwise, it surfaces as /ə/ (Kaye, Lowenstamm, \& Vergnaud, 1985).

Orthography signifies writing system of a language. Structures of different orthographies vary at the level of phonological awareness they represent and thus it can be assumed that orthographic domain is shaped by the nature of its writing system (Ziegler \& Goswami, 2005). Orthographies of various languages are controlled by different factors, e.g. Hindi orthography, Arabic orthography, and English orthography depend on phonological awareness, lexical awareness, and morphological awareness respectively (Pandey, 2007). With categorization of the nature of orthographies, syllabaries are such phonetic writing systems that represent the phonological units at the level of syllables. The Japanese Hiragana, for example, represents the syllable sound sequence /ka/ with the symbol か, $/ \mathrm{ki} /$ as き and $/ \mathrm{ku} /$ as く. Characters for $/ \mathrm{ka} /$, $/ \mathrm{ki} /$, and $/ \mathrm{ku} /$ in Japanese hiragana have no similarity to specify their common sound $/ \mathrm{k} /$. On the other hand, alphabetic writing systems represent sounds at the smallest pronounceable segment of speech which is a phoneme. Thus, a syllable / ka/ represents two graphemes of English, i.e., ' $k$ ' and ' $a$ '. Indic writing systems, on the contrary, represent phonological units at both the syllabic and alphabetic levels concurrently (Bright, 1996; Nag, 2011).

\section{History and description of Brahmi}

In India, Brahmi evolved and flourished around third century B.C.E. during the Ashokan regime (272-326 B.C.E). The edicts of Ashokan period extensively represents the Northern-Brahmi script (Verma, 1971). Experts of Paleography have primarily considered the Ashokan Brahmi a fully matured writing system. As Upasak (1960, p. 21) explains,

"Brahmi may have begun as a mercantile alphabet, based either on vague memories of the Harappa script or derived from contact with Semitic traders, indeed it may have owed to both these sources; but by the time of Ashoka, it was the most developed and scientific script of the world." 
Similarly, Basham (1967) argues that the documentation of Brahmi script, to represent the Sanskrit phonology in the Ashokan inscriptions, shows a rich and long developmental history of it.

Brahmi has been linguistically adapted for the genesis of several scripts in the area of Indian subcontinent as well as in South-East Asia. The scripts used for writing IndoAryan, Dravidian, Austro-Asiatic, Tibeto-Burman trace their roots back to the Brahmi. Hindi, Gujarati, Tamil, Telugu, Kannada, Malayalam, Bengali, Assamese, Punjabi of India, Sinhala in Sri Lanka, Tibetan, Javanese, Khmer, Thai, Burmese in South East Asia use scripts based on Brahmi (Gelb, 1963; Ruhlen, 1991). Roop (1972, p. ix) states that "the extent of early Indian influence in continental South-East Asia is nowhere more apparent than in the use of Indian writing systems for noncognate languages covering large parts of the latter area."

The outset of the architecture of Brahmi can best be perceived by making an outright connection with the linguistic design of the oral mode of learning in Vedic India. Knowledge, in the Vedic time (5000 B.C.E.), was transferred from one generation to the next through the tradition of Shruti (hearing) and Smriti (memory). Shruti, referring four Vedas, is created in the language of Vedic Sanskrit having a fixed accent which was used to converse in musical notes. This oral tradition authorises nobody to make a single change of the Shruti even at the level of a syllable. This rigidity made disciples learn the Shruti (hence, the literature hearing or Vedas hearing) with acute phonetic precision. While, Smriti, written in laukika Sanskrit, has been defined as the literature composed by self-realization of sages whose fundamental thoughts are primarily based on the comprehension of the Shruti (Kapoor, 2002; Mukherjee, Nema, \& Venkatesh, 2012). Scharfe (1977, p. 130) writes, "The Veda reciter had to learn how to constitute the continuous text from the word-for-word text, observing the rules of vowel and consonant sandhi as well as those of accentuation." Based on these facts we can argue that the Shruti and Smriti tradition have hugely affected the structure and design of Brahmi and the scripts derived thereafter.

Theories propounded to trace the origin of the Brahmi script have broadly been divided into two groups: 1) theories that associate their origin with an indigenous source, and 2) theories that trace their origin from some foreign source. The theory of the indigenous origin of Brahmi includes scholars like, Lassen and Edward Thomas, who credited the origin of Brahmi to the Dravidian races of South-India (Cited in Upasak, 1960). This assumption was probably based on the Aryan-Dravidian theory. Historians claim that Dravidians inhabited entire India before the advent of Aryans in this land. Also, Dravidians were culturally more advanced than Aryans, hence invented the writing system much before the Aryan's settlement (Pandey, 1957). Since the theory was based on presumptions, it fails to get the proper recognition from the esteemed scholars. Among others, Pandit G.H. Ojha (1959, cited in Upashak 1960, p. 13) very strongly asserts in his books that "Brahmi letters were developed in India out of 
pictographs and were later perfected to best suit the phonological character of the languages. No foreign influence can possibly be traced through the formation of letters." Another supporter of the indigenous origin of Brahmi, an Indian scholar R. Pandey $(1957$, p. 50) advocates that “... Brahmi characters were invented by the genius of Indian people and were derived from pictographs, ideographs, and phonetic signs, the earliest specimens of which are to be found in the Indus Valley inscriptions." An eminent Indian epigraphist, D. C. Sircar (1967, p. 30), envisages that "the Brahmi alphabet seems to have derived from the pre-historic Indus Valley script of a semipictographic nature and was popular in the major parts of Bharatvarsha."

The exponents of the second theory, who believed that Brahmi originates from some foreign source, are Otfried Muller, James Prinsep, and E. Senart (Upasak, 1960). They developed and endorsed the theory that Brahmi script had had its source in the Greek script. It was Otfried Muller, who put forward the idea that Greeks introduced the concept of alphabet to Indians when Alexander invaded India. Scholars from the same school of thought also speculated that Greek or Phoenician models imparted the notions to Ashoka's Buddhists to derive their letters (Upasak, 1960). However, these theories have been discarded as they do not support the paleographic and linguistic evidence. William Jones, a philologist of the 19th century, connected the genesis of Brahmi script to the Semitic origin (Taylor, 1883), and thereafter had been supported and followed by innumerable scholars. The views on the Semitic origin theory are roughly divided into three groups, cf. onto those who believe it originates from (1) Phoenician, (2) South-Semitic, and (3) North Semitic. G. Buhler in his book Indian Paleography (1904) propounded one of the most influential theories which had received a wide acceptance in Western scholarship for several decades. According to his theory, Brahmi script was derived from an Aramaic alphabet in 8th century B.C.E. He made a comparison between Brahmi and North Semitic alphabets and concluded that twenty-two letters of the Brahmi script were (directly) derived from the North Semitic alphabets, of which some are found in early Phoenician inscriptions (Hartmut Scharfe, 2002; Upasak, 1960). However, Buhler's theories have been challenged and discarded by several Indians as well as Western scholars (for example, see R. Pandey, 1957; Salomon, 1998). Amid the tussle between several theories propounded over the origin of Brahmi script, it is nowadays well accepted that Brahmi alphabets were perfect on phonetic measures.

\section{Devanagari}

Brahmi-derived scripts are mainly divided into two groups; namely, Gupta (northern group) and Grantha (southern group). The scripts of Dravidian and a few Austro-Asiatic languages are based on Grantha, while Devanagari and the other scripts of NorthernIndia are derivatives of the northern group, i.e. Gupta (Patel, 1995). Devanagari, a third 
generation offshoot of Brahmi, turned to be the most widely used script in India by the 11th century. In modern India, it coexists with nine other major scripts, including Roman and Perso-Arabic (Vaid \& Gupta, 2002). Initially, Devanagari was developed for writing Indo-Aryan classical language Sanskrit, and gradually its use extended to several modern Indo-Aryan languages, like Hindi, Dogri, Nepali, Marathi, Konkani etc. The extension of Devanagari to write other languages, apart from Sanskrit 'conditioned' it with few changes as it was required to represent specific speech-sounds of the newly adopted languages. This conditioning excludes, for instance, the sign ardha-visarga or jihvāmuliya which means "produced at the root of the tongue" from the modern Devanagari script to write Hindi (Bhat, n.d.; Egenes, 1996). Moreover, a few sounds have been borrowed during the course of development and historical changes. Sounds like $/ z /, / x /, / \gamma /, / q /$ (Perso-Arabic) have been adopted and are being represented by putting a dot beneath the consonant letters $ज(/ \mathrm{d} 3 /)$, ख $\left(/ \mathrm{k}^{\mathrm{h}} /\right)$, ग $(/ \mathrm{g} /)$, and $\mathbf{\text { क }}(/ \mathrm{k} /)$ to accommodate the contemporary phonological needs of Hindi.

The positioning of alphabets in Devanagari is strictly phonetic, with vowels and diphthongs occurring first and then followed by a sequence of consonants. Vowels, called svára (meaning the reverberation of self) begin with short $अ(a)$ followed by its long counterpart आ $(\bar{a})$. Explaining the short अ (a) vowel, Bhatt (n.d., p. 3) in his paper states that 'the ancient Indian Śikşa Āçārya-s (phonetician-s) consider $a$ [अ] as the primary sound that appears immediately at the entry point as the pulmonary breathair enters the vocal tract at the glottis.' In the arrangement of vowels, priority has been given to vowel-length over nasality (nāsikya). The arrangement of letters is in accordance to the place of articulation; for example in vowels, the velar अ (/a/), आ $(/ \bar{a} /)$ is followed by the palatal इ $(/ \mathrm{i} /)$, ई $(/ \bar{i} /)$ and the labial उ $(/ \mathrm{u} /)$, ऊ $(/ \bar{u} /)$. Other vowels listed thereafter are palatal ए (/e:/) and ऐ (/ع:/); velar ओ (/o:/) औ (/œ:/). The ऐ and औ are two velar-palatal and velar-labial diphthongs respectively. The nasal sound has been represented independently as अं (ã). Consonants (vyañjana) are positioned from velar to labial where obstruents (SparSa) occur first, followed by

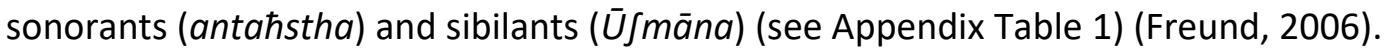

The phonemic units, i.e. consonants and vowels, in Devanagari are represented by two sets of symbols referred (to) as primary and secondary forms. To spell words, the use of these primary and secondary forms is specifically rule-bounded. Mostly, it is the position of a phoneme in a word which determines the rules assigned to both forms. $A$ vowel's primary form is used either when it comes at the beginning of a word or represents a full meaningful unit at its own. The secondary form for vowels, in Hindi, is called mātra. These mātras are frequently used in Devanagari after a consonant in a syllable. For example, in Hindi, primary and secondary forms for the vowel /e:/ are 'ए' and ' '. The primary form is used in the word like एक (/e: $\mathrm{k} /$, one) and the secondary form in the word पेड़ (/pe: $/$ /, tree). Among consonants, the secondary form is used when it comes at the initial or non initial position in a consonant cluster like, पाण्डेय (/pa:nde:j/, a surname) or पदस्थ (/pə'dəst $\mathrm{t}^{\mathrm{h}}$, in position). The primary form is used for 
all consonants other than the clusters, occurring at different places in a word. In consonants, the frequency of use of the primary form is much higher than that of vowels, while the secondary form of vowels, i.e. mātra, is more common in writing. Moreover, in Brahmi-derived scripts mātra also represents the unit of time. A small vowel is attributed to the value of one mātra, a long vowel associates with two mātras and a consonant with half of mātra (Patel, 1995).

\section{Akshara in Devanagari}

Akshara is the orthographic unit of Brahmi scripts. Historically, some researchers have considered it as a precursor of a mora. In North and South Indian languages, the fundamental topographic encoding and the phonological principles are the same but the special visual shape of akshara differs (Vaid \& Gupta 2002). Those writing systems that use akshara, like Devanagari, share multiple characteristics with a syllabary but at the same time contain alphabetic features (Nag 2011). Each akshara symbol in a syllabary, represents a syllable. In Hindi, for example, the akshara चा, चि, चू, constitute /t Jə:/, /tfi/, /t $\int \mathrm{u}: /^{1}$ syllable units. Furthermore, these akshara units can be deconstructed into smaller phonemic units, which show the alphabetic nature of

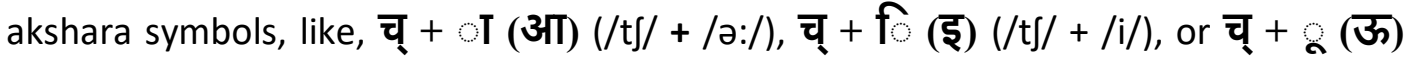
$(/ \mathrm{t} / \mathrm{+} / \mathrm{u}: /)$. These individual consonant and vowel sounds within syllable units $/ \mathrm{t} \jmath \curvearrowright: /$, $/ \mathrm{t} \mathrm{j} /$, /t $\mathrm{t} \mathrm{u}: /$ resemble English alphabetic sounds, being represented as [ch $+\mathrm{a}],[\mathrm{ch}+\mathrm{i}]$, $[\mathrm{ch}+\mathrm{u}]$.

An akshara can form a nucleus either by itself or with an onset. In case of a coda, it can be formed by itself or can be shifted to the next akshara to assimilate into the onset of the next syllable. There are four main types of symbols in the akshara system; (1) consonants with an intrinsic schwa (Сə), (2) consonants without an inherent short schwa vowel which is marked by a halant (C), (3) consonants with other vowels (CV), and (4) consonant clusters (CCV). Consonant clusters can be formed with more than two consonants such as CCCV or CCCVV (Nag, 2011; Patel, 1995). However, Pullum (1971) argues that simply putting together two consonant symbols in Devanagari script does not make a consonant cluster as it does in English. A consonant cluster in Devanagari script is represented by a composite symbol, which is a blend of its component sounds. The visuospatial characteristics of the consonant clusters might have a minimal resemblance to the physical appearance of the letters representing their component sounds. For example, Hindi akshara च represents $/ \mathrm{t} J /$, क represents $/ \mathrm{k} /$, and $₹$ represents $/ \mathrm{r} /$, so that put together thus चकर would represent $/ \mathrm{t} \int \mathrm{s} \mathrm{kgr} /$. However, the accepted Hindi term is चक्र (Wheel) consisting the composite symbol of

\footnotetext{
${ }^{1}$ Phoneme symbols used are from the IPA, 2002.
} 
क and र sound as क्र (/kr/). The composite symbol of क and र as क्र would now behave like a regular consonant symbol in writing.

Orthographical structure of Devanagari script follows a left-to-right sequencing. It is consonants in the script that follow a strict left-to-right linear order, whereas vowels are positioned non-linearly around them. In writing, vowels act as an adjunct to consonants occurring above, below, or on either side of it, representing the sound sequencing of their spoken forms. However, there are some exceptions where the leftto-right order in writing does not follow the order in which the speech sounds occur. Unlike other vowels, the short vowel/i/, which is represented by the symbols- इ (primary form, placed at the initial position) and (secondary or diacritical form, placed at non-initial positions), is attached to the left of the following consonant. Thus, the positioning of a short vowel /i/ creates a discrepancy between written and spoken sequences resulting in $\mathrm{Ci}$ (consonant $+/ \mathrm{i} /$ ) in speech and $\mathrm{iC}(/ \mathrm{i} /+$ consonant) in writing. This can be illustrated with the following example: a word दिल / $\mathrm{dr} / /$ is written with a vowel diacritic placed before / $d /$, making the sequence of a medial vowel, an initial consonant, and a consonant (Gaur, 1995; Pullum, 1971). Another distinctive feature of Brahmi-derived scripts, particularly of Devanagari, is that there is a horizontal line going across the top of each word.

\section{Nature of Brahmi-derived Scripts: alphabetic, syllabic, alphasyllabic, or something else}

The script is a cultural product and its origin and history are placed in a cultural context. Several cultures, in the course of their development, devised their own tools to record their languages. In other cases, already existing writing systems have been adopted to record their languages, or have at least inspired people to create new scripts for their speeches (Upasak, 1960).

I. J. Gelb, one of the pioneering figures in modern times, conducted the most extensive study of the origin and nature of writing systems and general principles of their development. Gelb (1963) in his analysis of writing systems of the world propounded that all scripts, from their origin to full evolution, follow a specific unidirectional stage of development. In his writing, he asserted that no script could skip developmental stages, being logography, syllabography and alphabetography. He writes $(1963$, p. 201) that "no writing can start with a syllabic or alphabetic stage unless it is borrowed, directly or indirectly, from a system which has gone through all the previous stages." Further, he states that "there can be no reverse development, i.e., an alphabet can not develop into a syllabary, just as a syllabary can not lead to the creation of logography." Gelb (1963, p. 144), however, takes a different stand, elsewhere, while describing the origin of Semitic writing. He claims that "the forms are freely invented with new values as found in a large number of writings such as Balti, Brahmi etc." His 
descriptions suggest that he has not addressed the complex identity and developmental process of Brahmi. Contradicting Gelb's categorization, scholars have contended the misguided belief that scripts can only be of three types; logography, syllabary and alphabetic. Similarly, scholars have questioned Gelb's claim of historical evolution and his set stages of development. Daniels (2000; 2002) states that Gelb misleadingly tried to develop an order and symmetry in whatever he explored.

While investigating the unique structure of Hindi writing system, Rimzhim et al. (2014, p. 5) concluded that Hindi orthography is 'functionally predominantly alphabetic'. To claim their argument, they state that "the presence of both full and half forms of vowels puts them orthographically on a par with the full and half forms of consonants respectively... This equivalence is a defining feature of an alphabetic writing system." In response to Rimzhim et al., Share and Daniels (2015) published a paper and listed six reasons why Brahmi-derived scripts should not be called 'alphabetic'. Presenting structural evidence they contended that consonants and vowels are not on a par, as the majority of vowels in Brahmi-derived scripts are not fullsized letters, and are mostly used as mātras or left unmarked by occurring inherently. Additionally, in contrast to Greek-derived scripts where consonants and vowels are physically similar, in Devanagari the shape and size of consonants and vowels are not alike, and vowels (in the form of mātras) are generally subjoined to consonants, which are larger in size. Further, consonants with a reduced status, i.e. consonants without an inherent short vowel, do not stand equally with a vowel as they maintain a noticeable appearance of the earlier form as a full-sized letter. In other points, too, consonants occur linearly ${ }^{2}$ while vowels are positioned nonlinearly, which makes them different from alphabetic systems.

Classification of the Indic writing system is problematic because it does not fit aptly to the traditional typology of writing systems. The specific consonantal syllabic structure with an inherent schwa vowel [Cə] confers a unique identity and sever it from other script categories. Akshara orthographic units, unlike alphabetic scripts, represent sounds at the level of a syllable but at the same time, unlike syllabary scripts, can be broken further into distinct phonemes (see Nag \& Sircar, 2008; Nag, 2007). In other words, Indian writing system is syllabic in terms of a syllable (or akshara) as a basic graphic unit, but it also reflects a contrary stand to a pure syllabary as discrete sound units of a syllable are identified individualy within the same syllable (Salomon, 1998). Based on these descriptions, a surprising number of scholars have attributed or easily accepted terms such as alphasyllabic, semi-syllabic, sub-syllabic, semi-alphabetic, or neosyllabic when defining the nature of Brahmi and its offshoots. By rejecting the term 'fundamentally alphabetic' in the context of akshara-based scripts, Share and Daniels $(2015$, p. 6), too, question the term 'alphasyllabic' as they state

\footnotetext{
${ }^{2}$ Except in the case of $/ r /$, which behaves like a vowel matra at the conjunct position.
} 
"[W]e argue that they (akshara based scripts) are not fundamentally syllabic. We begin by stating the obvious: in a syllabic script such as Japanese kana, syllable signs cannot be analysed into constituent consonants and vowels. Therefore, the term "alphasyllabic", suggesting that they are somehow a hybrid or mix of the two long-established types, is misleading."

We believe and argue $^{3}$ that the Brahmi-derived scripts should not be categorized as scripts with overlapping features of alphabetic and syllabic system as they contain categorization of their own. We suggest a new category named as 'akshara scripts'.

\section{Literacy development and teaching of akshara}

The role of orthography is to represent speech sounds of a language. Orthographies differ from each other in number of written characters they use to symbolize spoken sounds. Nag (2007) in her work on akshara languages estimated that a reader of akshara languages is required to recollect around 400 or more orthographic units. The learning condition of akshara orthographies became different from alphabetic scripts because of a large number of written symbols used. In Devanagari, for example, orthographic characters uniquely represent single speech sounds in almost all conditions; contrary to English written symbols, which represent more than one speech sound in different environments. Studies suggest (Nag \& Sircar, 2008; Nag, 2007) that orthographic learning of akshara system is slower than that of an alphabetic system. Children master letters of alphabetic languages somewhere by the end of their first year of schooling, whereas the akshara (akshar means letter) learning continues up to the fourth or fifth grade. Anand (1990) in his study on Hindi found out that fifth grade school children frequently make grapheme errors. To teach akshara symbols, a threestep learning is usually used in classrooms. Children are first taught the consonants with an inherent vowel (Cə), then the consonants with other vowel makers (CV), and finally consonant clusters (CCV). The academically designed Indic script learning is, however, less popular and is being followed differently in places other than academic. Thus, for example, children speaking Kannada ${ }^{4}$ get the exposure of CCV symbol unit with the rudimentary $\mathrm{C}$ symbol unit in their early textbooks, which result in the simultaneous learning of both units (Nag \& Sircar, 2008; Nag, 2011).

Several approaches have been adopted or coined to teach Indic scripts; shapesimilarity and productive-symbols are two such approaches (Gupta, 2007). For learners of Brahmi-derived scripts, visuospatial characteristics of symbols have always been the issue, rather than sound-symbol correspondence. Like English alphabets ' $v$ ' - ' $w$ ' or ' $b$ '

\footnotetext{
${ }^{3}$ David L. Share and Peter T. Daniels (2014) argue the same as 'Brahmi-derived scripts are in a category of their own and merit a unique descriptor.'

${ }^{4}$ Kannada is a prominent language of the Dravidian language family, mainly spoken in the southern part of the Indian subcontinent.
} 
- ' $d$ ', which are highly confusing for dyslectic or slow learners, Hindi orthography contains a huge number of symbols with mutual visuospatial characteristics. To solve this issue, Kerslake and Aiyer (1938) wrote a book titled 'Tamil Course for European Schools,' to teach Tamil to students through the shape similarity method. Further, the Central Institute of Indian Languages (CIIL), while developing teaching materials for Indic scripts, categorized written symbols of Devanagari script into eleven categories according to the similarity of their shapes (see Appendix Table 2). Prime objective of such categorization is to make students familiar with possible orthographic details of each written character (see Pattanayak, 1991; Rao, 1978).

In case of the productive symbols method, sounds are clubbed together meticulously to teach basic vocabulary of the language. Mace (1962) in his book developed a new sound sequencing to teach Persian script. For instance, three letters are introduced first - [a], [n], and [b], and then joined in a way to form basic possible words of Persian like ab (بآب water), baba (بابا father), an (ان that), nan (نان bread), and banana (بنانا builder). This method has been used to devise script-learning for Indian languages (see Eklavya, 2003; Jayaram, 2008), where symbols are put together in accordance with principles of economy and consistency, to create words immediately. To teach letters of Hindi script, Eklavya (2003) in his book introduces an unconventional sound sequencing. For instance, at one stage, he made the following sound arrangements: क /kə/, ब/bə/, स /sə/, म/mə/, प /pə/, न /nə/, ल /lə/, and a diacritic for /a:/, and at another stage he formed words like न + ल = नल (nə + lə = nəl, tap), क + ल $=$ कल $(\mathrm{k} \partial+\mathrm{l} ə=\mathrm{kəl}$, tomorrow), and फ $+\overline{\mathrm{c}}=$ फल (phə+lə = phəl, fruit, result). In Devanagari, when two consonants are put together the inherent vowel at word end is deleted automatically. Instead of following the conventionally phonetic arrangement of letters starting with independent vowels, he focused more on diacritics along with consonants. It is the diacritics in Devanagari, rather than the independent vowel forms, that are used overwhelmingly. Hence, with this approach, children generally learn the complete word at a time, while they also get familiar with the grapheme-phoneme mapping in Hindi language.

To spell words correctly, it is essential for a child to master the skill of connecting individual phonemes with corresponding orthographic units. The process of spelling makes a child aware of the units of meaning (morphemes), and the grapho-phonic knowledge of a language (Weeks, Brooks, \& Everatt, 2002; Westwood, 2005). However, strong impact of the phonological domain has been observed over the orthographic domain, which suggests that both the domains are not on a par. Unique dialectical sounds in a child's spoken language, varying from the standard spoken and written sounds, are difficult to spell as discrepancy emerges between the standard phonological unit and the one that a child has inherited though dialectical sounds. In Kannada, for instance, Nag et al. (2010) found out that the glottal / $\mathrm{h} /$ sound is difficult for children to spell correctly as an inconsistency occurs between mapping the standard spoken and the written form by a specific dialect feature. 
Share and Daniels (2015, p. 11) suggest that if Brahmi-derived scripts are considered as alphabetic in nature, then all scientific advancement in the field of English literacy learning can be implemented on them. On the contrary, if Indic scripts merit a unique identity based on the features they show as an orthography, "instruction will need to focus on more psycholinguistically accessible supra-phonemic units."

\section{Conclusion}

The nature of Brahmi-derived scripts, particularly of Devanagari, is often termed as alphasyllabic. Some researchers believe that the alphasyllabic attribution to the Indic scripts can be found in overlapping features of alphabetic and syllabary writing systems. On the contrary, there are some researchers who assert that the Indic scripts are neither fundamentally alphabetic nor fundamentally syllabic. It is because of the strong influence on the Indian academia of the identity and methods that originate in the Western academia, the attributions like alphasyllabic or semi-alphabetic for Bhramiderived scripts are readily accepted. It is essential to understand that the complex architecture of Devanagari script superficially presents some alignment with the alphabetic as well as syllabic properties. However, the fundamental property of akshara units of the Devanagari script is distinctive in its nature. Thus, the Devanagari script should not be termed as any of the two types and demand a unique descriptor.

\section{References}

Anand, V. (1990). Hindi spelling: Errors and remedies. Bhavana Prakashan.

Anderson, J. M., \& Ewen, C. J. (1987). Principles of dependency phonology. Cambridge: Cambridge University Press.

Basham, A. L. (1967). The Wonder that was India. New York: Mac.

Bhat, R. (n.d.). Devanagari. Retrieved from https://www.academia.edu/11307177/DEVANAGARI

Bright, W. (1996). The devanagari script. In P. T. Daniels \& W. Bright (Eds.), The World's Writing Systems (pp. 384-390). Oxford University Press.

Bühler, G. (1904). Indian Paleography, from about BC 350 to about AD 1300. Bombay education society's Press, Vol. 1.

Castles, A., \& Coltheart, M. (2004). Is there a causal link from phonological awareness to success in learning to read? Cognition, 91(1), 77-111. https://doi.org/10.1016/S00100277(03)00164-1

Egenes, T. (1996). Introduction to Sanskrit. Motilal Banarsidass Publ. Retrieved from http://abhidharma.ru/A/Raznoe/Yaz/Ind/0001.pdf

Eklavya (2003). Padho Likho Maza Karo: Part 1. Bhopal: Eklavya.

Freund, P. F. (2006). Vedic literature reading curriculum. Available from ProQuest Dissertations \& Theses Global. 
Gaur, A. (1995). Scripts and writing systems: A historical perspective. In I. Taylor \& D. R. Olson (Eds.), Scripts and literacy (pp. 19-30). Dordrecht: Kluwer Academic.

Gelb, I. J. (1963). A study of writing (Revised edition). Chicago, IL: University of Chicago Press.

Retrieved from

https://oi.uchicago.edu/sites/oi.uchicago.edu/files/uploads/shared/docs/study_writng.pdf

Gordon, M., \& Ladefoged, P. (2001). Phonation types: a cross-linguistic overview. Journal of phonetics, 29(4), 383-406. https://doi.org/10.1006/jpho.2001.0147

Gupta, R. (2008). Initial literacy in Devanagari: What matters to learners. South Asia Pedagogy and Technology 1. University of Chicago. Retrieved from http://hdl.handle.net/11417/1140

Jayaram, K. (2008). Early Literacy Project-Explorations and Reflections, Part 2: Interventions in Hindi Classrooms. Contemporary Education Dialogue, 5(2), 175-212. https://doi.org/10.1177/0973184913411166

Kapoor, S. (2002). The Indian Encyclopedia; Biographical, Historical, Religious, Administrative, Ethnological, Commercial and Scientific. New Delhi: Cosmos Publishing

Kaye, J., Lowenstamm, J., \& Vergnaud, J.-R. (1985). The internal structure of phonological elements: a theory of charm and government. Phonology, 2(1), 305-328. https://doi.org/10.1017/S0952675700000476

Kerslake, P. C., \& Aiyar, C.R. Narayanaswami. (1938). Tamil Course for European Schools. Madras: The Christian Literature Society for India.

Mace, J. (1962). Teach yourself modern Persian. London: English Universities Press.

McCarthy, J. J. (1981). A prosodic theory of nonconcatenative morphology. Linguistic inquiry, 12(3), 373-418. Retrieved from http://www.jstor.org/stable/4178229

Mukherjee, P. K., Nema, N. K., Venkatesh, P., \& Debnath, P. K. (2012). Changing scenario for promotion and development of Ayurveda-way forward. Journal of Ethnopharmacology, 143(2), 424-434. https://doi.org/10.1016/j.jep.2012.07.036

Nag, S. (2007). Early reading in Kannada: The pace of acquisition of orthographic knowledge and phonemic awareness. Journal of Research in Reading, 30(1), 7-22. https://doi.org/10.1111/j.1467-9817.2006.00329.x

Nag, S. (2011) The akshara languages: what do they tell us about children's literacy learning? Language-cognition: state of the art, 291-310. http://citeseerx.ist.psu.edu/viewdoc/download?doi=10.1.1.472.5579\&rep=rep1\&type=pdf

Nag, S., \& Sircar, S. (2008). Learning to read in Bengali: Report of a survey in five Kolkata primary schools. Bangalore, India: The Promise Foundation.

Nag, S., Treiman, R., \& Snowling, M. J. (2010). Learning to spell in an alphasyllabary: The case of Kannada. Writing Systems Research, 2(1), 41-52. https://doi.org/10.1093/wsr/wsq001

Ojha, G. H. (1959). Prachina Bharatiya Lipimala.

Pandey, P. (2007). Phonology-orthography interface in Devanāgarī for Hindi. Written Language \& Literacy, 10(2), 139-156.

https://www.jnu.ac.in/Faculty/pkspandey/papers/final_proofs-_devnagari_script.pdf

Pandey, R. (1957). Indian palaeography (Vol. 1). Motilal Banarasi Das.

Patel, P. G. (1995). Brahmi scripts, orthographic units and reading acquisition. Scripts and literacy: Reading and learning to read alphabets, syllabaries, and characters, 7, 265. https://link.springer.com/chapter/10.1007/978-94-011-1162-1_17 
Pattanayak, D. P. (1991). Language, education, and culture (Vol. 46). Central Institute of Indian Languages.

Pullum, G. K. (1971). Indian scripts and the teacher of English. ELT Journal, 25(3), 278-284. https://doi.org/10.1093/elt/XXV.3.278

Rao, G. S. (1979). Literacy methodology: papers presented at the National Seminar on Methodology of Literacy Material Preparation at Mysore in 1978 (Vol. 3). Central Institute of Indian Languages.

Rimzhim, A., Katz, L., \& Fowler, C. A. (2014). Brāhmī-derived orthographies are typologically Āksharik but functionally predominantly alphabetic. Writing Systems Research, 6(1), 4153. https://doi.org/10.1080/17586801.2013.855618

Roop, H. D. (1972). An introduction to the Burmese writing system. New Haven: Yale University Press.

Ruhlen, M. (1991). A guide to the world's languages: Classification (Vol. 1). Stanford, Calif: Stanford University Press.

Salomon, R. (1998). Indian epigraphy: A guide to the study of inscriptions in Sanskrit, Prakrit, and the other Indo-Aryan languages. New York: Oxford University Press.

Scharfe, H. (1977). Grammatical literature (Vol. 2). Wiesbaden: Otto Harrassowitz Verlag.

Scharfe, H. (2002). Kharosti and brahmi. Journal-american oriental society, 122(2), 391-393. https://www.jstor.org/stable/pdf/3087634.pdf

Share, D. L., \& Daniels, P. T. (2016). Aksharas, alphasyllabaries, abugidas, alphabets and orthographic depth: Reflections on Rimzhim, Katz and Fowler (2014). Writing Systems Research, 8(1), 17-31. https://doi.org/10.1080/17586801.2015.1016395

Sircar, D. C. (1957). Inscriptions of Asoka. Publications Division Ministry of Information \& Broadcasting.

Taylor, I. (1883). The alphabet: an account of the origin and development of letters (Vol. 2). K. Paul, Trench \& Company.

Upasak, C. S. (1960). The history and palaeography of Mauryan Brāhmī script. Nava Nālandā Mahāvihāra.

Vaid, J., \& Gupta, A. (2002). Exploring word recognition in a semi-alphabetic script: The case of Devanagari. Brain and Language, 81(1), 679-690.

https://dspacepre1.library.tamu.edu/handle/1969.1/158735

Verma, T. P. (1971). The palaeography of Brāhmi script in north India, from c. 236 BC to c. 200 $A D$. Siddharth Prakashan.

Weeks, S., Brooks, P., \& Everatt, J. (2002). Differences in learning to spell: Relationships between cognitive profiles and learning responses to teaching methods. Educational and Child Psychology, 19(4), 47-62.

Westwood, P. (2005). Spelling: Approaches to teaching and assessment. Aust Council for Ed Research.

Ziegler, J. C., \& Goswami, U. (2005). Reading acquisition, developmental dyslexia, and skilled reading across languages: a psycholinguistic grain size theory. Psychological bulletin, 131(1), 3. doi:10.1037/0033-2909.131.1.3 


\section{APPENDIX}

Table 1: Phonological inventory of an Indic script

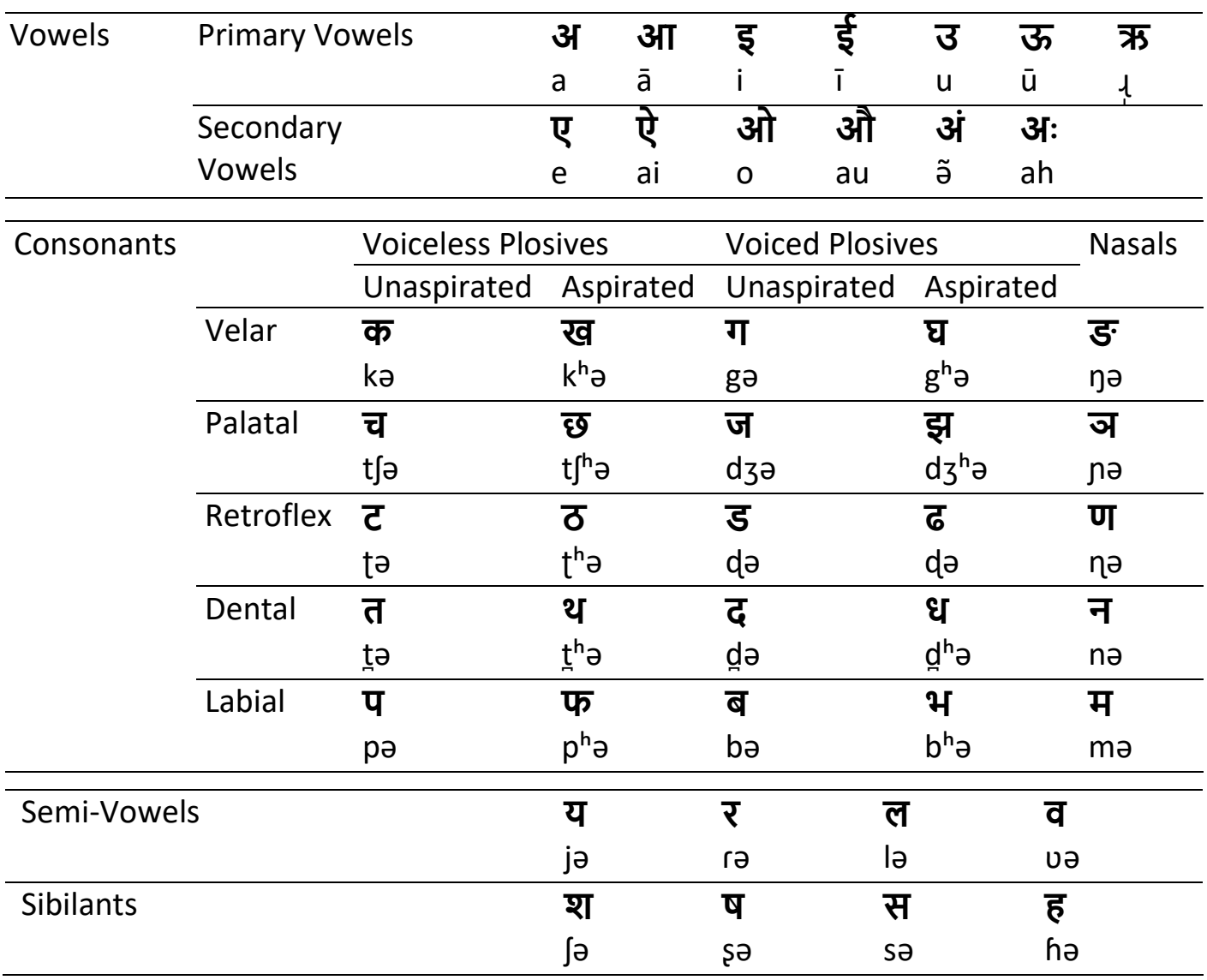

Table 2: Symbols based on shape similarity

\begin{tabular}{|c|c|c|}
\hline Group & Devanagari Symbols & Pronunciation \\
\hline 1 & व, क, ब & טə, kə, bə \\
\hline 2 & ग, म, भ, झ & $g \partial, m \partial, b^{h} \partial, d 3^{h} \partial$ \\
\hline 3 & र, स, ख , ए, ऐ, श & rə, sə, $k^{h} \partial, e:, a i, ~ J ə$ \\
\hline 4 & ण, प, ष, फ & 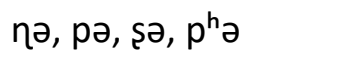 \\
\hline 5 & त, न, ल & tə , nə, lə \\
\hline 6 & ट, ठ, ढ, ढ' , द & $t \partial, t^{h} \partial, d^{h} \partial, r^{h} \partial, d$ \\
\hline 7 & ड, ड़ , इ , ई , ह & də, rə, i, i , hə \\
\hline 8 & घ, ध, छ & $\mathrm{g}^{\mathrm{h}} \partial, \mathrm{d}^{\mathrm{h}} \partial, \mathrm{t} \int^{\mathrm{h}} \partial$ \\
\hline 9 & च, ज & $t \int \partial, d z \partial$ \\
\hline 10 & उ , ऊ, अ , आ, ओ, औ & $\mho, \bar{u}$, , $, \bar{a}, \mathrm{o}:, \mathrm{J}:$ \\
\hline 11 & य, थ & $\mathrm{j} \partial, \mathrm{t}^{\mathrm{h}} \partial$ \\
\hline
\end{tabular}

